\title{
Myzomolgus sipunculensis sp. nov. (Cyclopoida, Catiniidae), a new copepod associated with sipunculan worms from Brazil
}

\author{
Terue C. Kihara 1; Tagea K. S. Björnberg ${ }^{2} \&$ Gisele Y. Kawauchi ${ }^{3}$ \\ ${ }^{1}$ Departamento de Zoologia, Universidade de São Paulo. Rua do Matão, Travessa 14, 101, São Paulo, São Paulo, Brasil. \\ E-mail: tkihara@ib.usp.br \\ ${ }^{2}$ Centro de Biologia Marinha, Universidade de São Paulo. Caixa Postal 71, 11600-970 São Sebastião, São Paulo, Brasil. \\ ${ }^{3}$ Department of Organismic and Evolutionary Biology, Harvard University. 16 Divinity Avenue, BioLabs, room 1119 , \\ Cambridge, MA 02138, USA.
}

\begin{abstract}
Catiniid copepods are characterized by the presence of a pedunculate sucker on the antenna. Four genera are currently included in the family Catiniidae: Catinia, Cotylemyzon, Cotylomolgus and Myzomolgus, the most speciose. Within the framework of the Special Research Program "Conservation and Sustainable Use of the Biodiversity of the State of São Paulo - Biota/FAPESP", a new species of Myzomolgus was found as an external associate of Sipunculus nudus and S. phalloides phalloides. The sipunculan worms were collected during the low tide

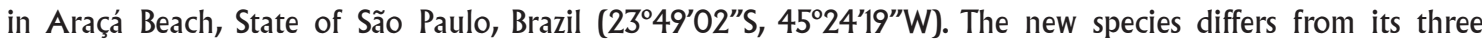
congeners, namely $M$. stupendus from France and $M$. tenuis and M. orientalis from Korea, by the peculiar ornamentation of the third antennal segment, morphology of mandible and leg 6 and presence of denticulate area between maxillipeds. The description of this new species raises to four the number of catiniid species (one of Catinia and two of Myzomolgus) associated with the widely distributed S. nudus. In Brazil, this is the first record of Myzomolgus and the second species associated with sipunculan worms (a new species of Catinia found on S. phalloides phalloides is under description).
\end{abstract}

KEY WORDS. Marine parasite; Sipunculus; taxonomy.

RESUMO. Myzomolgus sipunculensis sp. nov. (Cyclopoida, Catiniidae), um novo copépode associado a sipuncúlidos do Brasil. Os copépodes catiniídeos se caracterizam pela presença de uma ventosa pedunculada na antena. Atualmente, quatro gêneros estão incluídos na família Catiniidae: Catinia, Cotylemyzon, Cotylemolgus e Myzomolgus, o mais especioso. Como parte de um programa especial de pesquisa “Conservação e Uso Sustentável da Biodiversidade do Estado de São Paulo - Biota/FAPESP", uma nova espécie de Myzomolgus foi encontrada associada à superfície externa de Sipunculus nudus e S. phalloides phalloides. Os sipuncúlidos foram coletados na Praia do Araçá, Estado de

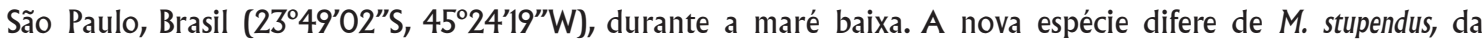
França, e M. tenuis e M. orientalis, ambos da Coréia do Sul, pela ornamentação peculiar do terceiro artículo da antena, morfologia da mandíbula e perna 6, e presença de área denticulada entre os maxilípedes. A descrição desta nova espécie eleva para quatro o número de catiniídeos (uma espécie de Catinia e duas de Myzomolgus) associados a S. nudus, um táxon de larga distribuição. No Brasil, este é o primeiro relato de Myzomolgus, e o registro da segunda espécie associada a sipuncúlidos (uma nova espécie de Catinia associada a S. phalloides phalloides encontra-se em descrição).

PALAVRAS-CHAVE. Parasita marinho; Sipunculus; taxonomia.

Within the framework of the Special Research Program "Conservation and Sustainable Use of the Biodiversity of the State of São Paulo - Biota/FAPESP", a new Catiniidae was found as an external associate of sipunculan worms. Although the concept of the family Catiniidae was not well established by BocQuet \& STOck (1957), Ho (1984) separated Catiniidae from Clausidiidae and Clausiidae, considering the large sucker on the antenna and the reduction of the female maxilliped.

Recent papers included Cotylemyzon Stock, 1982,
Cotylomolgus, Humes \& Ho, 1967 and Myzomolgus Bocquet \& Stock, 1957 with Catinia Bocquet \& Stock, 1957 in Catiniidae (Kim 2001, Boxshall \& Halsey 2004) and transferred Goidelia Embleton, 1901 to Echiurophilidae (Boxshall \& Halsey 2004).

The genus Myzomolgus has important apomorphies as terminal armature of maxilla with one pointed process and female maxilliped extremelly reduced (Ho 1984). This genus comprises 3 known species: M. stupendus Bocquet and Stock, 1957, M. tenuis Kim, 2001 and M. orientalis Kim, 2001.

Revista Brasileira de Zoologia 24 (3): 591-600, setembro 2007 


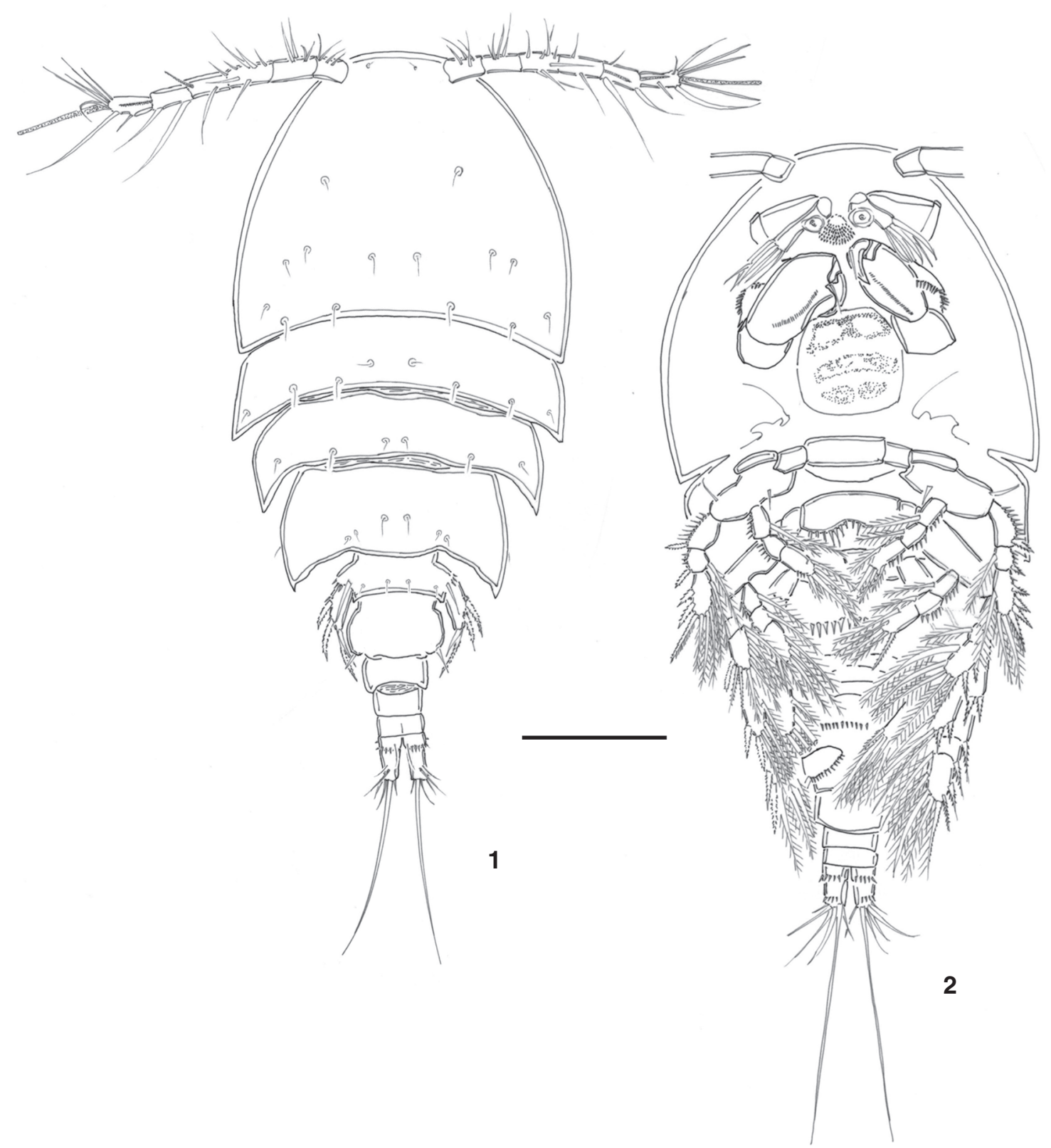

Figures 1-2. Myzomolgus sipunculensis sp. nov., male: (1) habitus, dorsal; (2) habitus, ventral. Scale bar $100 \mu \mathrm{m}$.

Myzomolgus was found before in the Channel, coast of France (Bocquet \& STOCK 1957), and in Korea (Кім 2001), associated with sipunculan worms. M. stupendus and M. tenuis attached to Sipunculus nudus L. and M. orientalis to Siphonosoma cumanense (Keferstein).

In Brazil, this is the first record of Myzomolgus and the second species associated with sipunculan worms (a new species of Catinia found on S. phalloides phalloides is under description elsewhere).

\section{MATERIAL AND METHODS}

The six male copepods studied were found attached to the external surface of sipunculan worms. Sipunculus nudus and S. phalloides phalloides, were collected by digging in the substrate during the low tide in Araçá Beach, State of São Paulo, Brazil (234' $02^{\prime \prime}$ S, $\left.45^{\circ} 24^{\prime} 19^{\prime \prime} \mathrm{W}\right)$. The copepods were relaxed with drops of propylenephenoxethol $0.2 \%$ added in the sea water and separated from the host. They were fixed in $4 \%$ formalin. 
Whole specimens were examined in temporary lactic acid mounts. Chips of cover slip were used to support the cover glass of the preparation. After examination, the material was returned to and preserved in 70\% ethanol. Dissections were made in glycerine and the dissected parts were placed on slides and sealed with Glyceel $^{\mathrm{o}}$.

Nikon Labophot ${ }^{\circledR}$ and Zeiss Axioskop 2 Plus $^{\circledast}$ compound $^{\circ}$ microscope equipped with differencial interference contrast, digital camera Nikon Coolpix $995^{\circledR}$ and camera lucida were used to examine and prepare the illustrations of the specimens.

The terminology applied to the segmentation and setation of body appendages was adopted from BoXsHALL \& HALSEY (2004).

\section{Myzomolgus sipunculensis sp. nov. Figs 1-29}

Material examined. São Sebastião, Araçá Beach (2349'02"S, 4524'19"W): six males, 09.X.2003. Three specimens on Sipunculus nudus, and three on S. phalloides phalloides in the intertidal zone; Kawauchi, G.Y. leg. Holotype (registration number: MZUSP 16461) deposited in Museu de Zoologia, Universidade de São Paulo. Dissected paratypes in collections of Dr Carlos E.F. da Rocha (Departamento de Zoologia, Instituto de Biociências, Universidade de São Paulo) and Dr Tagea K.S. Björnberg (Centro de Biologia Marinha, Universidade de São Paulo).

Description. Male. Body (Figs 1, 2): cyclopiform, slightly flattened. Total length, excluding setae on caudal rami, 0.435$0.530 \mathrm{~mm}(\mathrm{n}=6)$. Prosome longer than urosome (2.8:1). Largest width $(0.242 \mathrm{~mm})$ measured at posterior margin of second prosomite. Prosome (Figs 1 and 2): cephalosome fused to first pedigerous somite and 3 free prosomites. Cephalosome and free prosomites with sensilla pattern as shown in figure 1 . Epimera of second to fourth prosomites expanded posteriorly and with pointed posterior corners. Fourth prosomite wider than preceding free somites. Urosome (Figs 1-4): 6-segmented, about four times narrower than prosome, slightly tapering posteriorly. First urosomite bearing leg 5, with two pairs of dorsal sensilla (Fig. 3) and ventrally ornamented with two rows of spinules (Fig. 4). Genital somite (Figs 3 and 4) nearly rectangular, rounded laterally, with row of pre-marginal minute denticles on ventral aspect and naked seta on each posterior corner. Third urosomite (Fig. 4) with row of spinules on lateral corners. Fifth urosomite dorsal shape as in figure 3 . Anal somite (Figs 3-6) deeply cleft, shorter than 1/3 length of caudal ramus, with row of spinules along dorsal and ventral posterior margins; a naked seta inserted dorsally, near inner corner.

Caudal ramus (Figs 5 and 6) with parallel lateral margins slightly tapering posteriorly and armed with six setae. Seta I absent; setae II and IV dorsally implanted, the last one biarticulate; posterolateral seta III on outer distal corner; terminal setae IV and VI naked and weak; seta V well developed and about as long as urosome. Ramus expanded into rounded projection and with posterior row of spinules ventrally.

Rostrum: incorporated to cephalothorax.
Antennule (Fig. 7): 6-segmented, with setal formula: 4, $11,9,4+1$ aesthetasc, $2+1$ aesthetasc, $7+1$ aesthetasc.

Antenna (Figs 8-12): 4-segmented. First segment (Figs 8 and 9) about as long as lengths of three segments summed together, with patches of minute spinules on ventral surface (Fig. 8), and three rows of spinules along dorsal distal corner (Fig. 9). Second segment (Fig. 8) small, with row of spinules along inner margin. Third segment (Figs 8 and 10) with pedunculate cup-like sucker, flattened sharply pointed inner spine, and two setae; short seta denticulate at tip; long seta more than two times longer than last segment and bearing row of spinules curved backwards; last segment (Figs 8 and 11) with four distal setae denticulate apically, two lateral setae pinnate distally, and dorsal patch of spinules on posterior side, as in figure 11 .

Labrum (Figs 12 and 13): short, bell-shaped and strongly spinulate.

Mandible (Figs 14 and 15): prolonged into digitiform process bearing a pointed foliaceous element with one pinnate margin and 2 naked setae.

Paragnaths (Figs 15 and 16): racket-like structures, with rows of spinules on distal margin.

Maxillule (Fig. 17): 1-segmented, with four setae.

Maxilla (Figs 12, 18 and 19): foliaceous, with two pointed articulations posteriorly, usually covered by the maxilliped in entire specimens (Fig. 12); row of spinules along outer margin; anterior cap-like flap with 2 rows of spinules, one along posterior margin and one more anteriorly placed; inner margin with strong claw-like spine, bearing two small setae on dorsal view (Fig. 19).

Maxilliped (Figs 12, 20-22): robust, 4-segmented. First segment triangular, with inner pinnate spine. Second segment with rows of minute spinules along outer and inner margins, ventral face with long row of spinules covering a complex ornamentation as in figure 21; dorsal surface (Fig. 22) with two rows of long spinules and patch of smaller spinules. Third segment short and unarmed; distal segment, a very strong claw, with two bipinnate and one small glabrous seta on ventral side.

Labium (Figs 12 and 23): consisting of a triangular protuberance directed backwards and covered by minute spinules. Posteriorly to labium and between maxilliped bases, a rounded cushion-like area is covered by patches of spinules as arrowed in figure 12 .

Legs 1-4 (Figs 24-26): biramous, with both rami 3-segmented. Legs 2 and 3 similar. Intercoxal plate of leg 1 with row of minute spinules along posterior margin; those of legs 2-4 with strong spinules along convex edges. Pre-coxa ornamented with row of spinules along posterior margin of leg 1. Coxa of legs 1-4 with row of spinules at outer corner, leg 1 also with row of minute spinules along posterior margin. Basis of legs 1-4 with bipinnate setae on distal outer corner, and row of spinules along distal rim between exopod and endopod; leg 1 inner margin with row of minute spinules near endopod insertion and with row of spinules at insertion of bipinnate spine; legs 2 and 3 with row of setules 


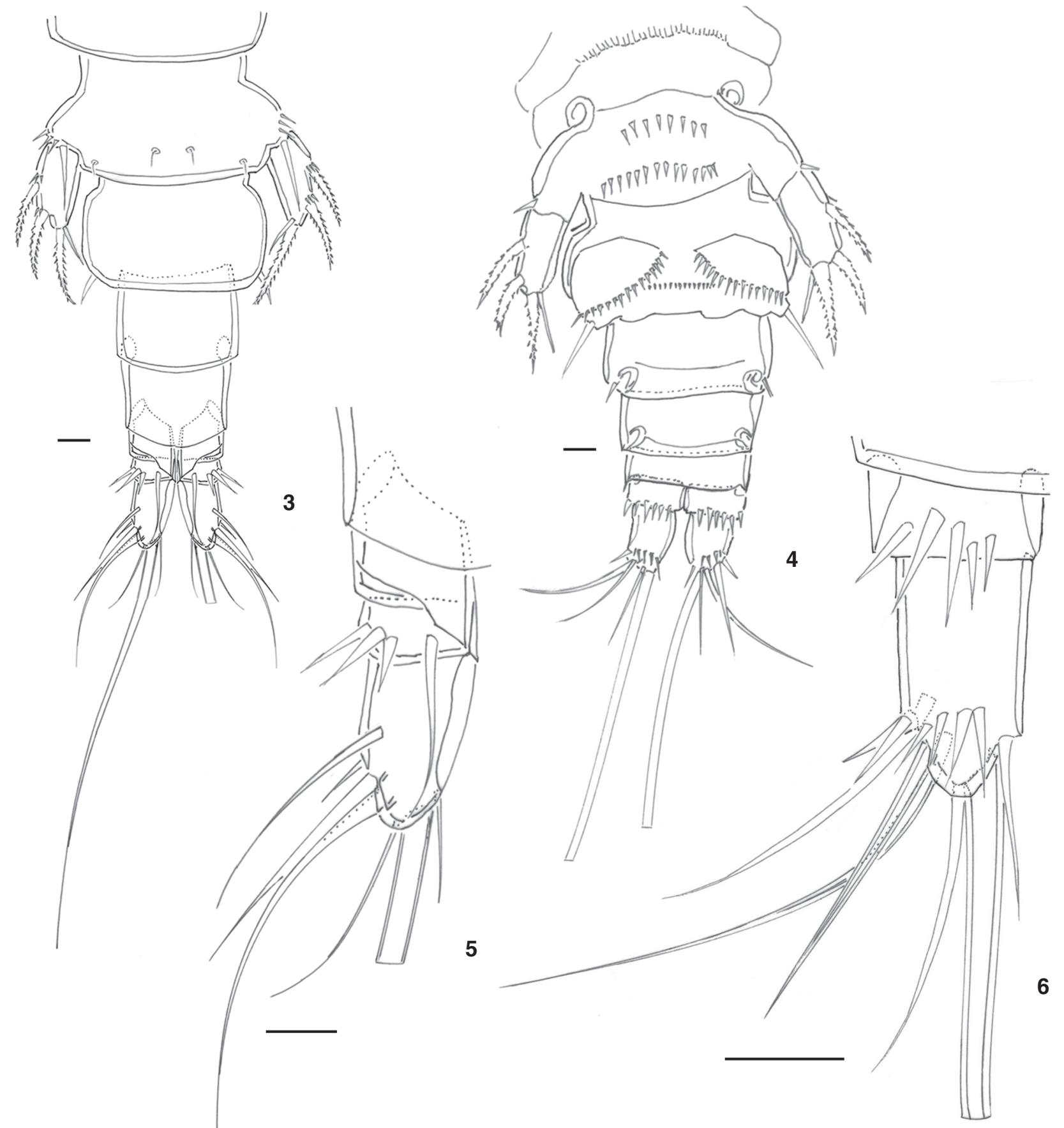

Figures 3-6. Myzomolgus sipunculensis sp. nov., male: (3) urossome, dorsal; (4) urossome, ventral; (5) terminal portion of urosome showing the left parts of pre-anal and anal somites, as well as the left caudal ramus, dorsal; (6) right portion of anal somite and respective caudal ramus, ventral. Scale bars $10 \mu \mathrm{m}$.

along inner margin. Inner and outer margins of exopods and endopods of legs 1-4 ornamented with setules and spines. Armature formula as follows (Roman numerals representing spines,
Arabic numerals representing setae): exopod - leg 1: I-0; I-1; III,1,3; leg 2: I-0; I-1; II,1,4; leg 3: I-0; I-1; II,1,4; leg 4: I-0; I-1; II,1,4; endopod - leg 1: 0-1; 0-1; I+1,1,3; leg 2: 0-1; 0-1; I+1,1,3; 


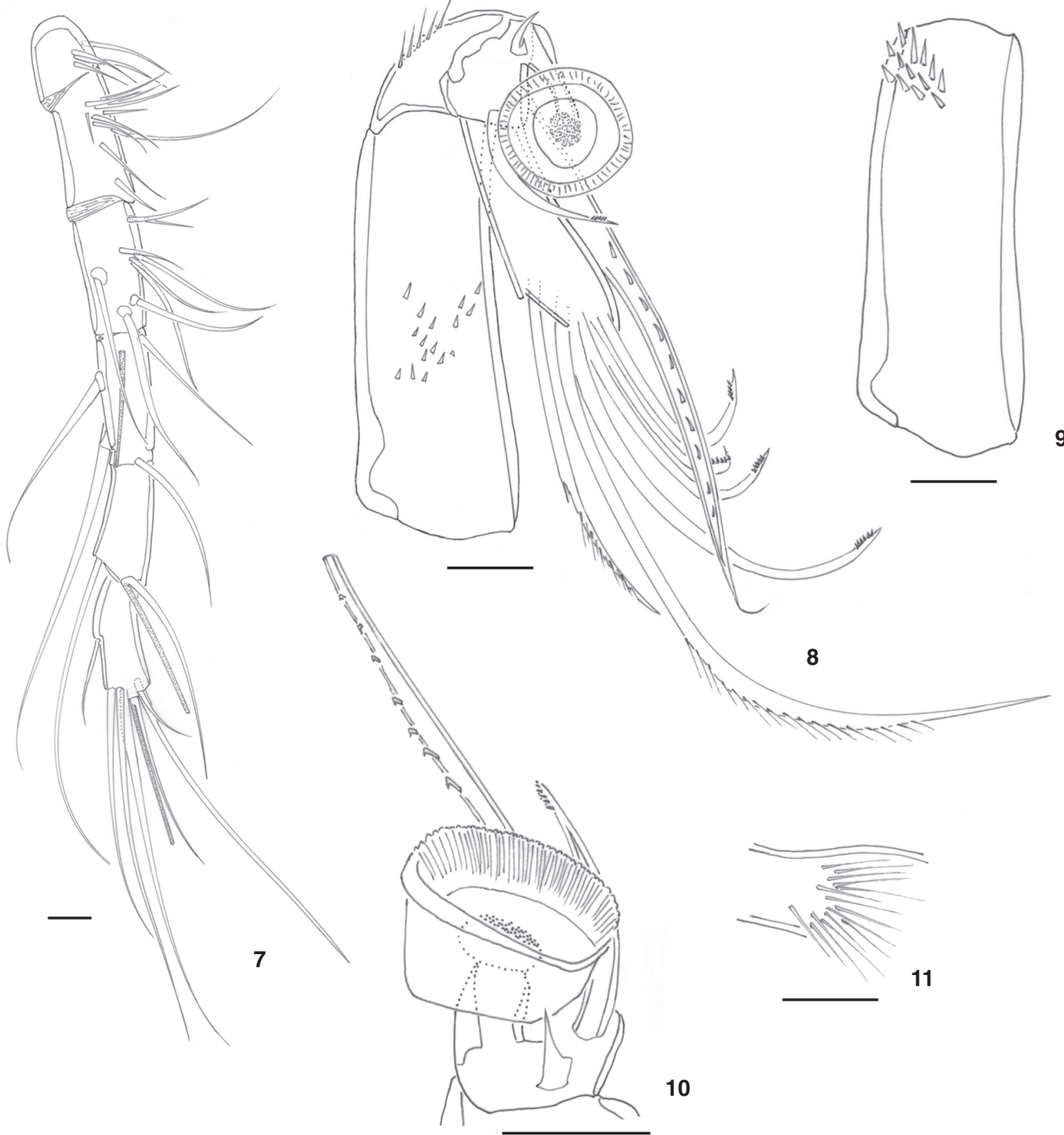

Figures 7-11. Myzomolgus sipunculensis sp. nov., male: (7) antennule; (8) antenna; (9) first antennal segment, dorsal; (10) third antennal segment, ventral; (11) distal area of the fourth antennal segment, dorsal. Scale bars $10 \mu \mathrm{m}$.

leg 3: 0-1; 0-1; I+1,1,3; leg 4: 0-1; 0-1; 1,1,2.

Leg 5 (Figs 27-29): 2-segmented; articulation of first segment of leg 5 and genital somite not discernible. First segment with spinules on outer distal corner and a naked seta on dorsal surface. Second segment with oblique row of spinules reaching distal end, two outer bipinnate spines with rows of spinules at insertion, a terminal bipinnate spine, and a subterminal naked seta. 


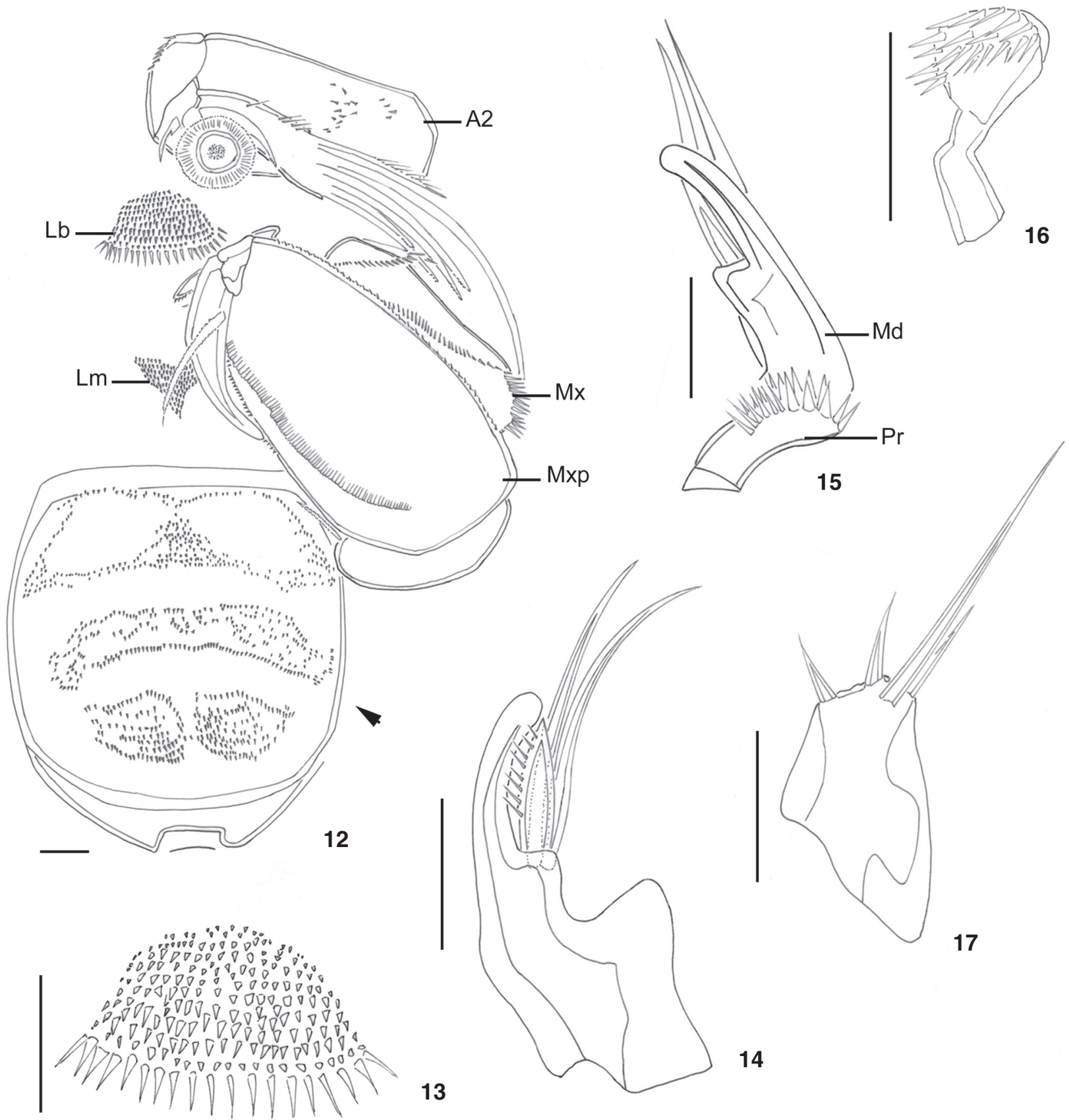

Figures 12-17. Myzomolgus sipunculensis sp. nov., male: (12) oral region; (13) labrum; (14) mandible; (15) mandible (Md) and paragnath (Pr); (16) paragnath; (17) maxillule. (A2) Antenna, (Lb) labrum, (Lm) labium, (Mx) maxilla, (Mxp) maxiliped, arrow head indicating the rounded cushion-like area covered by patches of spinules. Scale bars $10 \mu \mathrm{m}$.

Leg 6 (Fig. 29): represented by genital flaps with row of spinules along distal margin.

\section{DISCUSSION}

According to the key provided by KIM (2001), in which characters refer to both sexes, unless otherwise specified, and comparing with descriptions and re-descriptions of Catiniidae genera (Bocquet \& STock 1957, Humes \& Ho 1967, Sтоск 1982, KIм 2001), only Myzomolgus can accommodate our species.

The new species shows some resemblance with $M$. 


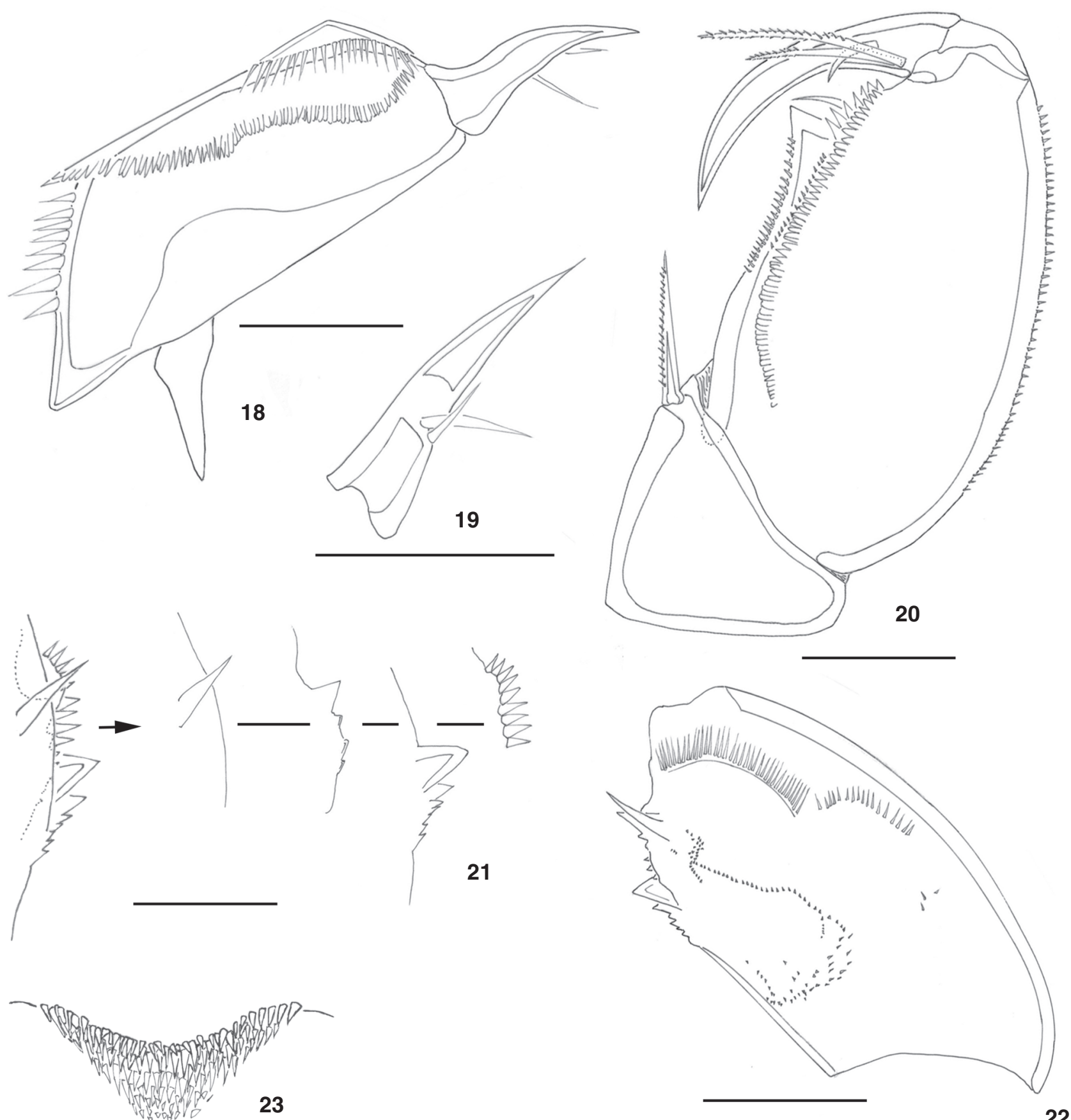

Figures 18-23. Myzomolgus sipunculensis sp. nov., male: (18) maxilla; (19) detail of the maxillary terminal spine; (20) maxilliped; (21) maxilliped second segment, dorsal; (22) detail of the second segment maxilliped ornamentation on inner distal area, and the same ornamentation separated in dorsal to ventral layers; (23) labium. Scale bars $20 \mu \mathrm{m}$.

orientalis in body shape, armature of the segments 3 and 4 of the antenna, shape of the labrum, general aspect of maxilliped, and setal formulae of legs1-4. Differences between the two spe- cies are in the length of caudal ramus, ornamentation of the antennule, maxilla and maxilliped.

Myzomolgus sipunculensis can be easily distinguished from 


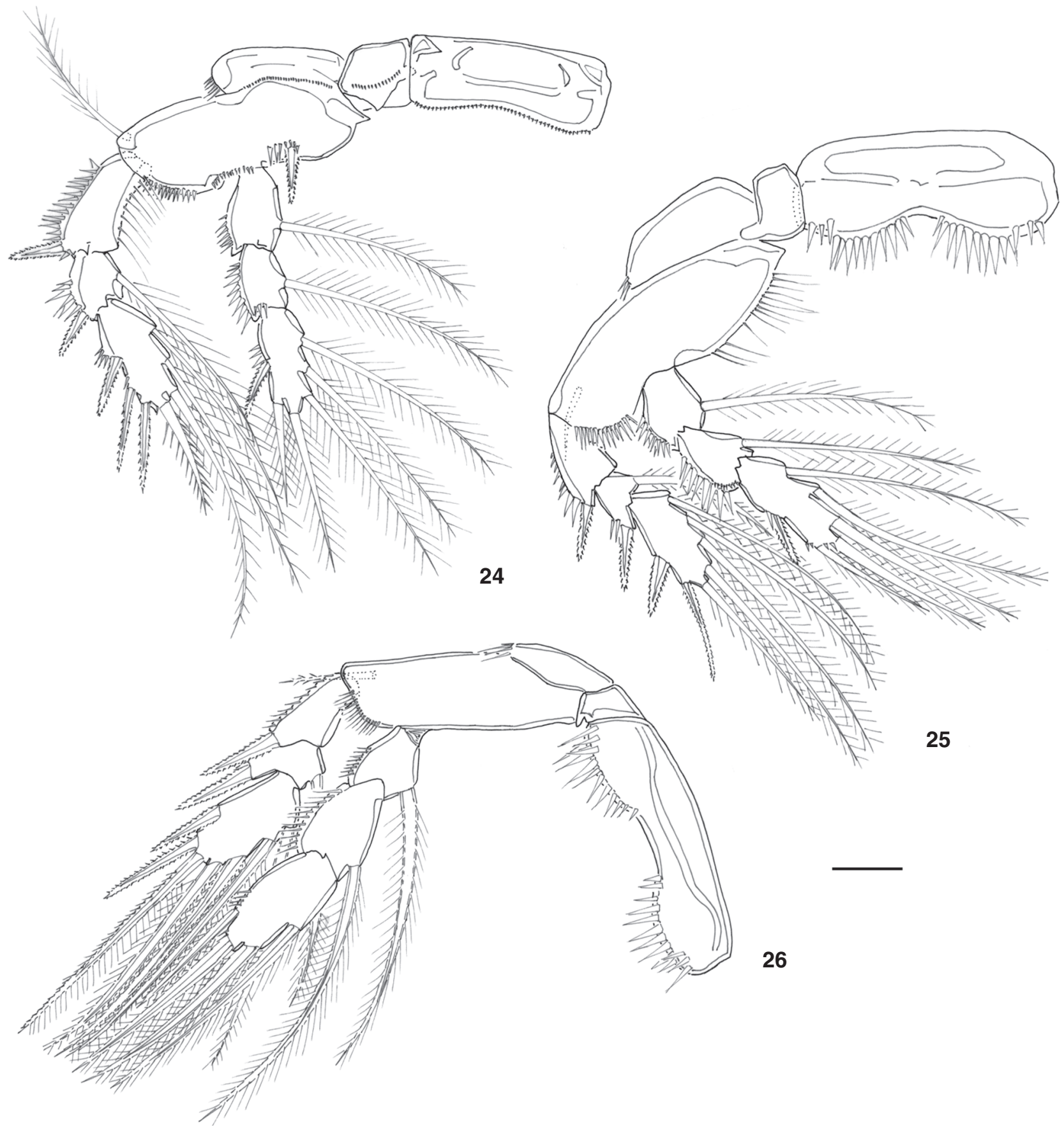

Figures 24-26. Myzomolgus sipunculensis sp. nov., male: (24) leg 1; (25) legs 2 and 3; (26) leg 4. Scale bar $20 \mu \mathrm{m}$.

its congeners by the peculiar ornamentation of the third antennal segment with a pedunculate cup-like sucker, a flattened spine, one small seta with a denticulate tip, and a long seta bearing claw like spinules. Other differential characteristics are the presence of one digitiform projection, 2 setae and one fo- liaceous element compounding the mandible, and the morphology of leg 6. In the new species, the denticulate area between the maxillipeds, the expanded epimera of second to fourth prosomites pointed posteriorly, and the spinulose labrum and labium are other remarkable features. 

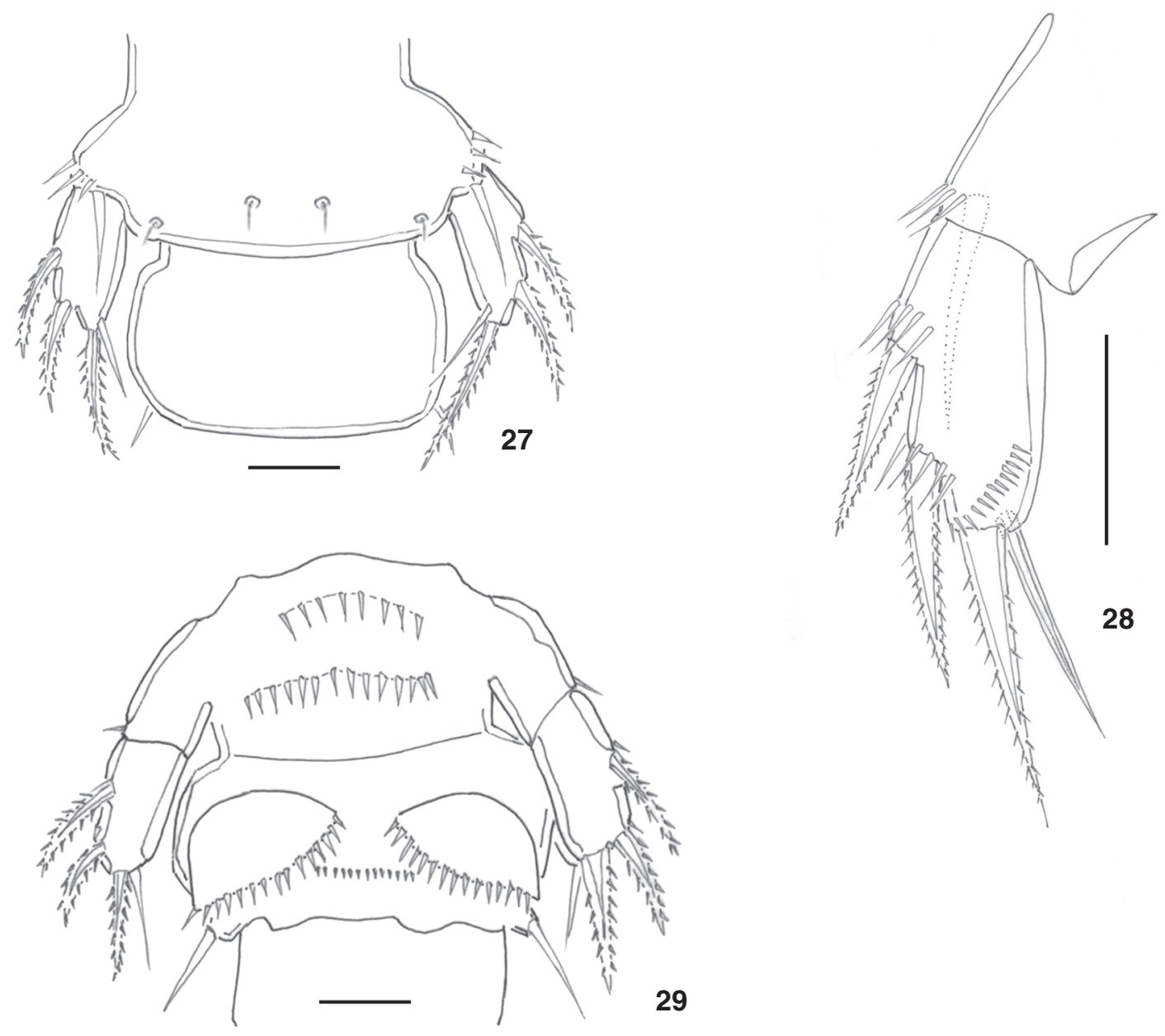

Figures 27-29. Myzomolgus sipunculensis sp. nov., male: (27) segment bearing leg 5 and genital segment, dorsal; (28) leg 5, ventral; (29) segment bearing leg 5 and genital segment with leg 6 . Scale bars $20 \mu \mathrm{m}$.

Previously found in France and Korea (Tab. I), this is the first record of the genus Myzomolgus in Brazil. The host list for Catiniidae is being enlarged by adding $S$. phalloides phalloides (Tab. I). Similar to Boucquet \& Stock (1957) who found $M$. stupendus and Catinia plana Boucquet \& Stock, 1957 attached to $S$. nudus, the new species also occurs together with Catinia on S. phalloides phalloides (G.Y. KAWAUCHI, personal obs.)

Although the key provided herein considered only male characters, it could be used as a supplement to the key published by Boxshall \& Halsey (2004) to identify Myzomolgus species, and will serve as a basis for future investigations.

\section{Key to the species of Myzomolgus (males)}

1. Limit between prosome and urosome indistinct; maxillae roundish; distal segment of antenna with very short setae (about as long as segment); endopod-3 of legs1-3 with four elements M. tenuis

1 '. Prosome distinctly separate from urosome, much narrower than prosome; maxillae not roundish; distal segment of antenna with long setae (at least twice as long as segment); endopod-3 of legs1-3 with six elements . 2

2. Second to fourth prosomites with pointed margins; mandible without spine M. sipunculensis

2 '. Second to fourth prosomites with rounded margins; mandible with spine

3. Outer margin of maxilliped claw smooth; antennule with plumose setae M. orientalis

3'. Outer margin of maxilliped claw denticulate; antennule without plumose setae M. stupendus

\section{ACKNOWLEDGEMENTS}

The authors gratefully acknowledge Prof. Dr. Carlos Eduardo Falavigna da Rocha for reviewing the manuscript. We are also grateful to the Centro de Biologia Marinha (CEBIMar) director and staff for the facilities put at our disposal, and to 
Table I. Geographic distribution and list of hosts of the known species of Myzomolgus.

\begin{tabular}{lll}
\hline \multicolumn{1}{c}{ Species } & \multicolumn{1}{c}{ Local } & \multicolumn{1}{c}{ Host } \\
\hline M. stupendus & Mortag Bay in la Manche, France & Sipunculus nudus Linnaeus \\
M. orientalis & Sinhung-ri, Jeju Island, Korea & Siphonosoma cumanense (Keferstein) \\
M. tenuis & Sinhung-ri, Jeju Island, Korea & Sipunculus nudus Linnaeus \\
M. sipunculensis & Ponta do Araçá, São Sebastião, Brazil & Sipunculus nudus Linnaeus \\
& & Sipunculus phalloides phalloides (Pallas) \\
\hline
\end{tabular}

the Instituto de Biociências of the Universidade de São Paulo, for the equipment and laboratory space.

This research was carried out under the BIOTA/FAPESP program - Bentos Marinho, a study made possible through support from FAPESP (Proc. 1998/07090-3 and 03/03822-0). We also thank the Coordenadoria de Pós-graduação, Pesquisa e Extensão do Centro Universitário Adventista de São Paulo (UNASP), Coordenação de Aperfeiçoamento de Pessoal de Nível Superior (CAPES) and the Conselho Nacional de Desenvolvimento Científico e Tecnológico (CNPq) for the financial support during the preparation of this work.

\section{REFERENCES}

BoceutT, C. \& J.H. Sтоск. 1957. Copépodes parasites d'Invertebrés des Côtes de France. IV a. Le double parasitisme de Sipunculus nudus L. par Myzomolgus stupendus nov. gen., nov. sp., Copépodes trés remarkables. Proceedings of the Koninklijke Nederlandse Akademie van Wetenschappen 60 (3): 410-417.
Boxshall, G.A. \& S.H. Halsey. 2004. An introduction to copepod diversity. The Ray Society, London, XV+966p.

Ho, J-S. 1984. New family of poecilostomatoid copepods (Spiophanicolidae) parasitic on polychaetes from Southern California, with phylogenetic analysis of Nereicoliform families. Journal of Crustacean Biology 4 (1): 134-146.

HumEs, A.G. \& J.-S. Ho. 1967. New cyclopoid copepods associated with polychaete annelids in Madagascar. Bulletin of the Museum of Comparative Zoology 135 (7): 377-413.

KІм, I.H. 2001. Redescription of Catinia plana Bocquet \& Stock, 1957 and description of two new species of Myzomolgus (Copepoda, Poecilostomatoidea, Catiniidae) associated with Sipunculans in Korea. The Korean Journal of Systematic Zoology 17 (1): 71-89.

Sтоск, J.H. 1982. Description de Cotylemyzon vervoorti gen. et sp. nov., un copépode cyclopoïde très original, parasite d'un polychète d'Amboine. Netherlands Journal of Zoology 32 (3): 364-373.

Received in 05.II.2007; accepted in 23.VII.2007. 